\title{
БІБЛІЙНА ГЕНЕЗА ШЕВЧЕНКОВИХ ОБРАЗІВ ЛЮБОВ І ПРАВДА ТА ІДОЛИ В ЧУЖИХ ЧЕРТОГАХ
}

\author{
ОКСАНА ДЗЕРА \\ Львівський національний університет імені Івана Франка, Львів - Україна \\ BIBLIJNA GENEZA KONCEPTÓW TARASA SZEWCZENKI \\ MIEOŚĆ I PRAWDA ORAZ IDOLE W OBCYCH PAEACACH
}

OKSANA DZERA

Lwowski Uniwersytet Narodowy im. Iwana Franki, Lwów - Ukraina

STRESZCZENIE. Artykuł poświęcony jest badaniu pochodzących z Biblii obrazów z Kobziarza Tarasa Szewczenki. W danych obrazach Szewczenko proponuje własną interpretację złożonych konceptów biblijnych, które w odmienny sposób zostały zwerbalizowane w różnojęzycznych tłumaczeniach Pisma Świętego.

\section{BIBLICAL GENESIS OF SHEVCHENKO'S IMAGES LOVE AND TRUTH AND IDOLS IN FOREIGN DWELLINGS}

OKSANA DZERA

Ivan Franko National University in Lviv, Lviv — Ukraine

ABSTRACT. The article investigates Biblical etymology of some images from The Kob$z a r$. T. Shevchenko provides his individual interpretation of complex Biblical concepts which are differently verbalized in translations of the Holy Scripture into different languages.

$\mathrm{Y}$

псалмах, „подражаніях” і поемах на біблійну тему, а також у творах без очевидного біблійного першоджерела Т. Шевченко трансформує біблійні сенси багатьох концептів, нашаровуючи національну інформацію й вербалізуючи в системно-повторюваних ключових словах, що, за термінологією М. Коцюбинської ${ }^{1}$, створюють своєрідний кругообіг образів у Шевченковій поетиці загалом. Уже через неї ці постійні образи набувають статусу культурних концептів, репрезентуючи українську культуру, а згодом й українську мовну картину світу. При цьому, на рівні рецепції вони функціонують як Шевченкові, народнопоетичні й біблійні водночас, адже кілька поколінь українців пізнавали Біблію через Кобзар.

Мета цієї статті - з'ясувати біблійну етимологію кількох Шевченкових образів, які сягають корінням складних концептів, що мають неоднозначну інтерпретацію в національних перекладах Біблії.

Перший такий образ - любов $i$ правда - простежуємо від давньогебрейського виразу hesed $i$ ěmet. Концепт е̌met розглядає зокрема С. Аверинцев, аналізуючи фразу із псалмів 35 (36) : 6 і 56 (57) : 11 в російському синодально-

${ }^{1}$ М. Коцюбинська, Кругообіг образів, [в:] В сім'ї вольній, новій, Шевченківський збірник, Київ 1989, вип. 5, с. 121-132. 
му перекладі, який і досі застосовує на богослужіннях Українська Православна Церква Московського Патріархату: „милость Твоя до небес, истина Твоя до облаков”, „до небес велика милость Твоя и до облаков истина Твоя”. Виникає питання, чому ж Божа істина може простиратися від землі тільки до хмар, а не до захмарних висот, адже Бог всюдисущий. Посилаючись на авторитетний словник Lexicon in Veteris Testamenti libros (ed. L. Koehler, Leiden E. J. Brill, 1985), С. Аверинцев доводить хибність традиції, що сягає Септуагінти та Вульгати,

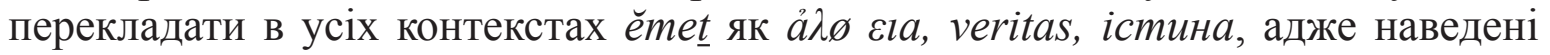
в словнику значення непохитність, стабільність, вірність і лише четверте істина: 1. Festigheit, Zuverlaessigkeit: firmness, trustworthliness; 2. Bestaendigkeit: stability; 3. Treue: faithfulness; і лише 4. Wahrnheit: truth. (...). Отже, на думку С. Аверинцева, йдеться не про істинність, а про вірність Бога Його завітові з людьми, „і тоді дуже природно назвати межею цієї вірності хмари (...)"2. До схожого висновку приходить польська дослідниця А. Свідеркувна; порівн.: „(...) староєврейське слово е̌met первісно означало не так „відповідність дійсності”, як грецька або наша „правда”, символом якої є світло, як радше дещо, на що можемо покластися 3 повною довірою, вірність, а може, швидше надійність, символом якої в Біблії, зазвичай була скеля"з.

Зачепивши цікаву проблему, С. Аверинцев залишає поза увагою першу частину завіту, спілки між Господом і людьми, яку переважно перекладають як милість, ласка, милосердя, а в давньогебрейському тексті вона вербалізується як hesed. Це слово, як і е̌met, $є$ неперекладним у сенсі пошуку однолексемного еквівалента; Біблійна енциклопедія Брокгауза визначає його як „вчинок, який винагороджує когось за відданість і вірність, за допомогу, (...), а також є свідченням любові” (пер. автор. - О. Д.) ${ }^{4}$. Поєднання концептів hesed та е̌met часто вербалізується в псалмах, де прославляється спілка Господа і людей; цими словами Господь називає себе, звертаючись до Мойсея, дослівно: „(...) Бог милосердний і милостивий, довготерпеливий", , [щедрий на hesed та ёmet (О. Д.)] (Вихід 34 : 6). Всі українські перекладачі Біблії в цьому контексті обирають однаковий відповідник до виразу „щедрий на hesed: „щедрий на милість, многомилостивий, багатомилостивий”. Як наслідок, виникає певна тавтологія, адже Господь двічі називає себе милостивим.

Більшість перекладачів у цьому контексті інтерпретують е̌met як правдивий, істинний. Лише I. Хоменко (1963) обирає лексему, що відображає суть Господнього завіту: вірний. Зазначимо, що таке перекладацьке рішення не випадкове. Трансфомуючи звертання до Господа, в 31 псалмі І. Хоменко знову перекладає émet як вірний: „В руки твої віддаю й духа мого: ти визволив мене, Господи, вірний Боже" (Псалом 31 : 6) ${ }^{6}$. Цей відповідник контекстуально підкріплюється 4-им віршем псалма: „Бо ти — скеля моя, й моя твердиня”. Однак усі інші українські перекладачі обирають усталений традицією вираз Боже правди / істини. Для прикладу, в англомовній традиції канонічна Біблія короля Якова 1611 р., наслідуючи латинську Вульгаmy, подає такий самий варіант God of truth, натомість англомовні перекладачі другої половини XX ст. замінюють його виразом faithful God; порівн.: „Into thy hand I commit my spirit; thou hast redeemed

${ }^{2}$ С. Аверинцев, Стилістичні проблеми перекладу Святого Письма, [в:] С. Аверинцев, Софія-Логос. Словник, Київ 2007, с. 476-477.

${ }^{3}$ А. Св ідеркувна, Розмови про Біблію. Старий Завіт, Львів 2008, с. 24.

${ }^{4}$ Ф. Ринекер, Г. Майер, Библейская эничиклопедия Брокгауза, Paderborn 1999, с. 580.

${ }_{5}^{5}$ Біблія або Книги Святого Письма Старого і Нового Заповіту, пер. І. Огієн ка, Київ 2002.

${ }^{6}$ Святе Письмо Старого та Нового Завіmу, пер. I. Хоменка, Ватикан 1990. 
Біблійна тенеза Шевченкових образів любов $i$ правда $m a$ ідоли в чужих чертогах 47 me, O Lord God of truth" (Ps. $31: 5)^{7}$; „I place myself in your care. You will save me, Lord; you are a faithful God"' (Ps. $31: 5)^{8}$.

Hesed y сучасних англомовних перекладах інтерпретується вже не як теrcy (милість), а як love. ${ }^{9}$ Таку інтерпретацію підтримують філологи-біблієзнавці, зокрема А. Свідеркувна вважає, що любов - найкращий варіант hesed, проте це любов дієва, вольова настанова, а не почуття: „hesed здійснюють, а не відчувають!"10. У цьому сенсі надзвичайно вдалим видається вираз shows great love як відповідник до виразу [щедрий на hesed] в англомовній Біблії Добра Новина. Таке тлумачення Старого Завіту прокладає логічний місток до відомої новозавітної номінації Господа із Першого Соборного Послання св. Апостола Івана „Бог - то любов” (1 Ів. $4: 8,4: 16)$.

Знаменно, що в перекладі Псалтиря П. Куліш ще наприкінці ХІХ ст. в певних контекстах, зокрема в проблемній фразі „ӗmet сягає небес”, обирає вірність відповідником до ёmet; порівн.: „Господи, милість твоя сягає на небеса, вірність твоя під хмари" (Псальма $36: 6)^{11}$. Те саме простежуємо й у перекладах I. Огієнка (1958) та I. Хоменка: „Господи, - аж до небес милосердя Твоє, аж до хмар Твоя вірність” (Пс. 35 (36) : 6; переклад І. Огієнка); „Милість твоя, Господи, небес сягає, вірність твоя по хмари" (Пс. 36 : 6; пер. І. Хоменка). Українські перекладачі XXI ст., покладаючись на церковнослов'янську Острозьку Біблію ${ }^{12}$ (Р. Турконяк, 2007) чи російський синодальний переклад (Патріарх Філарет, 2004), повертаються до помилкової, на думку деяких дослідників, icmuни (правди) порівн.: „Господи, Твоя милість на небі, а правда Твоя сягає небес” (Пс. 35 : 6; пер. Р. Турконяка) ${ }^{13}$; „Господи, милість Твоя до небес, істина Твоя понад хмарами" (Пс. 35 : 6; пер. Патріарха Філарета) ${ }^{14}$. До того ж, переклад Р. Турконяка ще більше спантеличує віруючого: виходить, що милість Господня на небі (а не сягає неба), тобто іiі можна очікувати лише після смерті. Утім, це не перекладацький недогляд, а наслідок дослівного відтворення тексту Септуагінти та Острозької Біблії.

Отже, в українських перекладах Старого Завіту не прослідковуємо однозначного підходу до вербалізації складних біблійних концептів hesed i ěmet. П. Куліш та I. Огієнко враховують контекст, у якому вжито е̌met, відтворюючи його як вірність або правда чи істина, І. Хоменко в усіх контекстах обирає слово вірність, а Р. Турконяк та патріарх Філарет в усіх контекстах наслідують церковнослов'янську традицію перекладати ёmet як істина чи правда. Відповідником до hesed усі українські перекладачі обирають лексему милість (інколи милосердя), що сягає церковнослов'янського перекладу, вкорінилася в літературній традиції ${ }^{15}$ та мовній системі (,з3 Божою милістю”), однак не охоплює

7 The Holy Bible (the King James Version), London s. a.

8 Good News Bible. The Bible in today's English version, New York 1976.

9 Першим англомовним перекладом Біблії, де відповідником hesed $є$ слово 3 морфемою love, стала Американська Стандартна Версія (1901): Thy lovingkindness, O Jehovah, is in the heavens; Thy faithfulness (reacheth) unto the skies (Ps. 36:5)

${ }^{10}$ А. Свідеркувна, зазн. джерело, с. 174.

${ }^{11}$ Святе Письмо Старого та Нового Завіm, пер. П. Куліша, I. Левицького та I. Пулюя, Київ 2003.

12 Порівн.: Господи, на небеси милость твоя, и истина твоя до облаков.

${ }^{13}$ Біблія. Книги Святого Письма Старого та Нового Завіту, пер. Р. Тур кон я ка, Київ 2013.

${ }^{14}$ Біблія. Книги Священного Писання Старого та Нового Завіту, пер. патріарх Філарет (Денисенко), Київ 2004.

${ }^{15}$ Напр. назва п’єси 1728 р., яку приписують Ф. Прокоповичу або І. Неруновичу, Милість Божа: „Милость Божія, Україну од неудобносимих обид лядських чрез Богдана Зіновія Хмель- 
всього комплексу значень оригіналу, його синергетики. Б. Грінченко виділяє в слові милость два значення: 1) милосердя, 2) любов. Ілюстрацією до другого значення в словнику Б. Грінченка слугує старовинна народна пісня, що $\epsilon$ своєрідною фольклорною інтерпретацією біблійного концепту hesed $i$ ěmet як милість i віра; порівн.: „О Боже мій несконченний! що ся тепер стало! Як то віра, так то віра, а милости мало"16. Словник украӥнської мови в 11 томах фіксує любов, кохання як значення слова милість із ремаркою заст., що свідчить про втрату словом цього значення в сучасному узусі. Проте в біблійному контексті Божа милість позначає Божу любов, хоч, мабуть, це значення дещо затерлося через конвенційне й часто неосмислене повторення фрази.

Попри тривалу традицію в англомовних перекладах і часткове вживання в українських, слово вірність як відповідник до е̌met $\epsilon$ неоднозначним, зокрема в Срусалимській Біблї - відомому французькому перекладі 1956 р., що вважається одним із найбільш адекватних і водночас найбільш поетичних, фразу hesed $i$ ěmet інтерпретують як amour et vérité (любов i правда); порівн.: „Yahvé, dans les cieux ton amour, jusqu'aux bnues, ta vérité” (Ps. 36 (5) : 6) ${ }^{17}$.

Як любов $i$ правда біблійний концепт hesed $i$ ёmet входить у метабіблійну поетику Т. Шевченка, а саме в його поеми на мотиви Нового Завіту Марія й Неофimu та поезію Пророк. Апостоли й пророк розносять по землі слово любові й правди; порівн..: „Неначе праведних дітей, / Господь, любя отих людей, / Послав на землю їм пророка; / Свою любов благовістить! / Святую правду возвістить!”'18; „Мужі воспрянули святиє. / По всьому світу розійшлись, / І іменем твойого сина, / Твоєї скорбної дитини, / Любов $i$ правду рознесли / По всьому світу ${ }^{19}$. Таким чином, Шевченкова традиція тлумачення проаналізованих концептів відрізняється від власне національної біблійної, при цьому кожна з них стає своєрідним каноном в мовній свідомості українця.

Переклад Святого Письма та його інтерпретацію часто ускладнює омонімія або паронімія ключових слів певного біблійного вірша. Ще в 1930-і роки цією проблемою зацікавився Дж. Ламса. Він навів приклад неправильно перекладеного біблійного виразу, що став фразеологізмом у сучасних європейських мовах — let the dead bury their dead / Зостав мертвим ховати мериів своїх (Матв. $8: 21-22)$. Сучасне значення цього фразеологізму — жити теперішнім і майбутнім, а не минулим ${ }^{20}$, „сміливо поривати 3 тим, що віджило, відмерло, зотліло” Джерелом цього біблеїзму є розмова Ісуса з учнем: „А інший із учнів промовив до Нього: „Дозволь мені, Господи, перше піти та батька свого поховати”. А Ісус йому каже: „Іди за Мною, і зостав мертвим ховати мерців своїх!”22. Тлумачення Дж. Ламси значно пом'якшує жорстку відповідь Ісуса: вислів поховати батька на Сході означає „подбати про батька аж до його смерті”, адже за давньою традицією літній чоловік уважався мертвим і підпадав під повну опіку старшого сина. Загадкову формулу щодо поховання мертвими мертвих дослідник уважає недоглядом перших перекладачів, які сплутали арамейські слова metta (мерт-

ницького, преславного військ запорозьких гетьмана, свободившая і дарованими єму над ляхами побідами возвеличившая (...)"

${ }^{16}$ Словарь украӥнської мови в 4 томах, упор. Б. Грінченко, Київ 1907, т. 2, с. 424.

${ }^{17}$ La Bible de Jerusalem, [in:] Electronic resource: http://studybible.info/version/Geneva(20.11.2012).

${ }^{18}$ Т. Г. Шевченко, Повне зібр. творів у 12 m., Київ 1989-1991, т. 2, с. 102.

19 Там само, с. 264.

${ }^{20}$ The Wordsworth Dictionary of Classical and Literary Allusions, London 1994, p. 58.

${ }^{21}$ А. Коваль, Спочатку було Слово: Крилаті вислови біблійного походження в украӥнській мові, Київ 2012, с. 170.

${ }^{22}$ Біблія або Книги Святого Письма Старого і Нового Заповіту, пер. І. Огієн ка, Київ 2002. 
Біблійна тенеза Шевченкових образів любов $i$ правда та ідоли в чужих чертогах 49

вий) і matta (місто). Мікроскопічні арамейські позначки для розрізнення цих слів могли затертися в давніх рукописах, що й змінило просту і логічну фразу „зостав місту ховати мерців своїх"23.

Іронічний ефект, затертий, на жаль, майже в усіх перекладах, створює паронімічна гра слів elohiym (Бог, точніше його старозавітна множинна форма) та eliylim (що зазвичай перекладається як ідоли, проте має значення пустоma, марнота, ніщзо) із Першої Книги хронік (Параліпоменона)16:26 та Псалма 95 (96):5, дослівний переклад: „Бо великий Yehovah (Господь) і прославлений; дуже слід боятися його понад усіх elohiym (богів). Бо всі elohiym (боги) народів є eliylim (ніщуо, марнота), а Yehovah (Господь) небеса сотворив" (підрядник О. Д.). Фонетично-графічна схожість і смислова антитеза паронімів іронічно акцентують увагу на фальшивій божественності тих, кому приписують функції Бога.

В усіх англомовних перекладах цього вірша, починаючи від XVI ст. проблемне слово eliylim відтворено як idol: „For all the gods of the nations are idols, but the LORD made the heavens" (Біблія короля Якова), при цьому спостерігається повна уніфікація варіантів у Першій Книзі хронік та Псалтирі. Окрім двадцятикратного повтору eliylim, у Старому Завіті є низка інших слів на позначення ідола як ,зображення сотворіння небесного або земного, чи такого, що живе й у воді, якому замість Бога поклоняються і служать"24. У широкому сенсі ,ідол - те, перед чим схиляються замість Бога, взагалі все те, що відволікає серце від Бога"25.

Українські перекладачі не одностайні в тлумаченні образу фальшивих богів. Вони пропонують різні варіанти навіть у межах одного перекладу. Таке тлумачення йде ще від церковнослов'янської, відтак і візантійської традиції, де відповідником eliylim у Першій Книзі Хронік є ідоли, а в Псалтирі - біси. Схожі варіанти пропонує послідовник візантійської традиції перекладу Р. Турконяк; порівн: „Адже всі боги народів - ідоли, а Бог наш сотворив небо” (Параліпоменон 16 : 26); „Адже всі боги народів - це демони, а Господь небеса сотворив" (псалом 95 (96) : 5). Цікаво, що образ демонів знаходимо у псалмі 96 ще й у Вульгаті та першому англійському перекладі Біблії Дж. Вікліфа (13821395), який використовував латинський текст як переклад-посередник; порівн.: „quoniam omnes dii gentium daemonia at vero Dominus caelos fecit ${ }^{26}$; „For alle the goddis of hethene men ben feendis; but the Lord made heuenes" ${ }^{27}$. Варіанти біси, демони зміщують смисловий акцент із суто ритуального до ,існування демонічних сил, які стоять за зображеннями бовванів”, i „загрожують людині, навіть якщо вона служить їм несвідомо"28.

Відрізняються й версії перекладу I. Хоменка, який у Першій Книзі Хронік актуалізує пряме значення eliylim у слові ніщзота, а в Псалмі 96 використовує синонім слова ідоли - кумири; порівн.: „Бо всі боги поганські - нішо$m a$, а Господь сотворив небеса”; „Бо всі боги поган - кумири, Господь же сотворив небо”.

${ }^{23}$ G. M. Lamsa, Idioms in the Bible Explained and a Key to the Original Gospel, London 1985, c. 100.

${ }^{24}$ Библейская эниииклопедия в 2-х т., Москва 1991, т. 1, с. 284.

25 Э. Нюстрем, Библейский словарь, Санкт-Петербург 1995, с. 159.

${ }^{26}$ Biblia sacra vulgatae, Antverpiae 1641.

${ }^{27}$ Wicliffe's Bible, [in:] Electronic resource: http://www.biblestudytools.com/wyc/ (14.05.2013).

${ }^{28}$ Ф. Ринекер, Г.Майер, указан. источник, с. 366. 
У Біблії 1903 р., попри те, що Перша Книга Хронік і Псалтир мають різних перекладачів - I. Нечуя-Левицького та I. Пулюя відповідно, eliylim має один відповідник - німо (нічо); порівн.: „Бо всі боги поганські нічо, а Господь сотворив небеса” (Паралипоменон 16:26; пер. І. Нечуй-Левицький); „Всі бо боги народів ніщз, Господь же сотворив небеса" (Псалом 96 : 5; пер. І. Пулюй). Схожий підхід спостерігаємо й у перекладі патріарха Філарета, хоч у псалмі 96 подано два відповідники eliylim - ніщо та ідоли; порівн.: „Бо ті боги народів німо - ідоли, а Господь небеса сотворив".

I. Огієнко - єдиний серед українських перекладачів, якому вдалося відтворити паронімічну гру elohiym - eliylim і при цьому не “пожертвувати" значенням: „Бо всі боги народів - божки, а Господь сотворив небеса”. Зменшувальна форма слова божок творить іронічний перегук із словоформою боги, підкреслюючи мізерність лжебогів, і водночас є синонімом до лексем iдол, кумир $^{29}$ у значенні скульптурної фігурки якого-небудь божества ${ }^{30}$. Така увага до формально-стилістичних засобів біблійного тексту загалом характерна для перекладацької стратегії I. Огієнка. Деякі з його перекладацьких рішень, скажімо, чоловікова, чоловічиия як відповідник до $i \check{s ̌ s} а$ (жінка) від $i \check{s}$ (чоловік), викликають небезпідставні звинувачення щодо “важкості” стилю. Проте наведений приклад свідчить про неабияке чуття слова й цілісне сприйняття тексту Святого Письма перекладачем.

Однак у широкому значенні ідоли - це не просто скульптурні фігурки, a „те, що стоїть між нами і Богом, чи те, чим ми підміняємо Бога”з1. У коментарі до псалма 96 М. Генрі зазначає, що під ідолами розуміють тогочасних правителів, яких часто оголошували богами після смерті чи навіть за життя возвеличували як богів нації ${ }^{32}$.

Саме таке розуміння ідолопоклонства стає визначальним у метабіблійній образній системі Т. Шевченка. У своїй творчості, на думку О. Яковини й О. Слободяна, поет однозначно висловлює несприйняття російсько-імперського візантійства в сенсі духовного й соціального рабства, де „цар стає „батюшкой”, тобто сакральною особою" "з3. Саме російських можновладців має на увазі Т. Шевченко в своєму „подражаніі” Осія. Глава XIV: „Брешуть боги, / Ті ідоли в чужих чертогах" ${ }^{34}$. Цей образ виходить на поверхню в поемі Неофimu, де Нерон проголошує себе „новим Юпітером”. Цікаво, що ієрархічно вибудувана згідно з римським „табелем о рангах” черга на молитву до бронзового кесаря (сенатори, патриції, преторіане, плебеї-гречкосії) нагадує сатиричний опис такої собі „ієрархії стусанів” Російської імперії із поеми Сон, порівн.: Дивлюсь, цар niдходить / До найстаршого ... та в пику / Його як затопить! / Облизався неборака: / Та меншого в пузо — / Аж загуло! А той собі / Ще меншого туза / Межи плечі, той меншого, / А менший малого, / А той дрібних, а дрібнота / Уже за порогом / Як кинеться по улииях, / Тай й давай місити / Недобитків православних, / А ті голосити; / Та верещать; та як ревнуть: / "Гуля наш ба-

${ }^{29}$ Словарь украӥнської мови у 4 m. ..., т. 2, с. 82 .

30 Словник украйнської мови у 20 m., головн. наук. ред. В. М. Русанівський, Київ 2010, T. 1 , c. 582 .

${ }^{31}$ Nelson's Illustrated Bible Dictionary, [in:] Electronic resource; PC Study Bible. New Reference Library, Copyright (c) 1986 (12.03.2013).

${ }^{32}$ Matthew Henry's Commentary on the Whole Bible, [in:] Electronic resource; PC Study Bible. New Reference Library, Copyright (c) 1991 (12.03.2013).

${ }_{33}$ О. Яковина, О. Слободян, Тарас Шевченко: істина - не комунікативна реальність, Київ 2013, с. 70.

${ }^{34}$ Т. Г. Шевченко, зазнач. джерело... т. 2, с. 269. 
Біблійна тенеза Шевченкових образів любов $i$ правда та ідоли в чужих чертогах 51 тюшка, гуля! / Ура! Ура! Ура!” / (...) Перед світом / Усе те заснуло, / Тільки де-де православні / По углах стогнали / Та, стогнучи, за батюшку / Господа благали... ${ }^{35}$.

Остання фраза цієї цитати „молитва за батюшку царя” відсилає до початкового рядка гімну Російської імперії Боже, изаря храни, що може розглядатися як приклад так званого залоллення біблійного тексту (термін А. Лефевра), тобто його зміни на догоду замовнику ${ }^{36}$. Відповідний вірш кілька разів повторюється в Старому Завіті, зокрема й у деяких перекладах Першої Книги Самуїлової 10 : 24; Другої Книги Самуїлової 16 : 16; Першої Книги Царів 1 : 25, 34, 39; Другої Книги Царів 11 : 12; Другої Книги Хронік 23 : 11.

Найбільш популярне й, здавалося б, найочевидніше його джерело - Псалом 20, що відомий під назвою Молитва за цуаря. Фінальний вірш Боже, спаси царя видається логічним підсумком цього псалма. Саме такого тлумачення вираз набуває в церковнослов'янському перекладі Біблії і в найновіших українських перекладах патріарха Філарета та Р. Турконяка (візантійська традиція), а також у Вульгаті та деяких англомовних перекладах, починаючи 3 перекладу Вікліфа ${ }^{37}$ (латинська традиція), зокрема в т. зв. Дуей-Реймській Біблії (1581) та Новій Міжнародній Версї̈ (1978); напр.: „Господи, спаси цุаря і вислухай нас, в який би день ми не звертались [до Тебе]” (пер. Філарета), „O LORD, save the king! Answer us when we call!" (Нова Міжнародна Версія) ${ }^{38}$. Близьким до цього тлумачення є переклад фрази як побажання цареві перемоги в перекладі I. Хоменка (,Дай, Господи, цареві перемогу; вислухай нас, коли взиватимемо до тебе”) і Добрій Новині: (,Give victory to the king, O Lord; answer us when we call”).

Проте можливі й інші інтерпретації залежно від розміщення паузи, а отже, й постановки знаків пунктуації. Деякі біблієзнавці прочитують тут благання до Господа прихилити для людей милість царя чи найімовірніше звертання до самого Бога, що акцентує увагу на його царському достоїнстві ${ }^{39}$. Відмінність між двома останніми інтерпретаціями залежить від написання слова цар 3 малої чи великої літер. Перше значення (прагнення ласки земного володаря) актуалізується в Женевській Біблї (1560) (,Save Lord: let the king hear us in the day we call”) ${ }^{40}$ та Біблії короля Якова („Save, LORD: let the king hear us when we call"). Достатньо змінити літеру на велику або переакцентувати звертання й стає зрозуміло, що в псалмі йдеться про Царя небесного; порівн.: „Господи, спаси! Царю, вислухай нас в день поклику нашого!” (пер. I. Пулюя), „Господи, спаси! Хай озветься нам Цар у день нашого кликання!” (пер. І. Огієнка), „Save, LORD! May the King answer us when we call" (Нова Версія Біблї короля Якова) ${ }^{41}$, „Save, Jehovah: let the King answer us when we call” (Американська Стандартна Версія $)^{42}$.

\footnotetext{
${ }^{35}$ Там само, т. 1 , с. 187.

${ }^{36}$ A. Le fevere, Mother Courage's Cucumbers. Text, System and Refraction in a Theory of Literature [in:] Translation Studies Reader, London, New York 2000, p. 233-249.

${ }^{37}$ Саме такий варіант увійшов до головного молитовника англіканської церкви The Book of Common Prayers (1662), що використовується під час літургії.

${ }^{38}$ The Holy Bible. New International Version, New York, 1978.

${ }^{39} \mathrm{C}$. Аверинцев, Собрание сочинений. Переводы, Київ 2004, с. 632; Matthew Henry's Commentary on the Whole Bible, Electronic Database. Copyright (c) 1991.

${ }^{40}$ Geneva Bible (1599), [in:] Electronic resource: http://studybible.info/version/Geneva (26.05.2013).

${ }^{41}$ The Holy Bible, New King James Version, Nashville 1982.

${ }^{42}$ American Standard Version of the Bible, [in:] Electronic resource: http://www.biblestudytools. com/asv/ (12.03.2013)
} 
Отже, висновкуємо, що інтерпретація фінального 9-го вірша 20-го псалма як благання за земного царя є своєрідною вторинною біблійною ідеологемою, що репрезентує лише один із можливих варіантів розуміння структурноневизначеного старозавітного вислову. Саме над цією ідеологемою іронізує Т. Шевченко в поемі Сон.

Розбіжність національних біблійних перекладів, як бачимо, часто породжена відмінністю інтерпретацій полісемантичних слів, де пряме значення породжує метафоричне, а метафора переростає в символ. Перекладна традиція щодо тлумачення неоднозначних біблеїзмів встановлює своєрідний канон у межах певної культури, порушити який можуть як нові переклади, так і літературні варіанти. Інтерпретуючи біблійні концепти, Т. Шевченко не тільки надає їм нового „олітературеного” сенсу, а інтуїцією генія повертає їм первинне значення, вкорінюючи його в український грунт. 